\title{
HUNGARIAN ARCHAEOLOGICAL EXPEDITION IN THE MOUNTAINS OF IRAQI KURDISTAN \\ Excavations undertaken by the Faculty of Humanities, Eötvös Loránd University, at Grdi Tle (Rania Plain)
}

\section{Gábor Kalla - Tamás Dezsó}

Hungarian Archaeology Vol. 8 (2019), Issue 4, pp. 1-12, https://doi.org/10.36338/ha.2019.4.4

In the frames of the expedition of the Faculty of Humanities of Eötvös Loránd University, Tamás Dezsö and Gábor Kalla carried out fieldwork in Kurdistan since 2016, at the tell settlement in Grd-i Tle. The tell (hill) is situated in the autonomous region of Iraqi Kurdistan, in the Rania Plain, surrounded by mountains, and it is one of the most important archaeological sites in this region. During the four, one-month long excavation campaigns, it was possible to clarify the basic topographical characteristics of the settlement, as well as historical and chronological details of its development. In addition to recovering significant archaeological remains dating from the Islamic and Hellenistic-Parthian periods, our preliminary assumptions were confirmed: the remains of an important administrative centre of the Neo-Assyrian Empire were found on the spot of this 30 metres high hill.

\section{RESEARCH OBJECTIVES AND SITE SELECTION}

The main goal of the research program was to study a peripheral administrative centre of the Neo-Assyrian Empire (9th-7th century BC). It is only by looking at the emergence and expansion, both at the centre and the occupied territories, that one would be able to understand the functioning of the Empire. Although some of the centres of Assyrian provincial administration have already been studied, these were predominantly located in the western territories (MACGINNIS - WiCKE - GreENFIELD 2016). Until about 5 years ago, the eastern confines had scarcely been studied archaeologically, and even the localization of places mentioned in written sources was extremely difficult, despite the importance of this borderland defending the Empire from its enemies beyond the high mountains, and supplying soldiers for the army and food for the core territories. Grd-i Tle seemed a suitable choice for multiple reasons. The hill is a spectacular landmark, towering over the surrounding landscape, which is the northwest parts of the Rania Plain (Fig. 1), and the surface finds, dating from the Neo-Assyrian period, already hinted on its chronology. In 2016, the war between the soldiers of the Islamic State and the Peshmerga forces of Iraqi Kurdistan was still going on, thus, for security reasons it was also advisable to choose a site distant from the frontline.

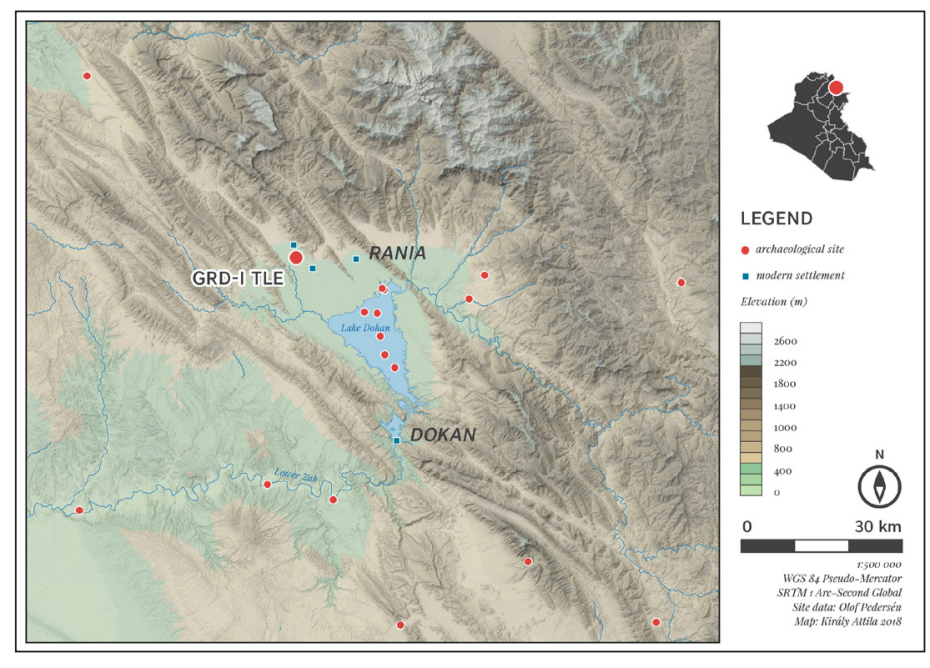

Fig. 1. The position of Grd-i Tle on the Rania Plain. Lake Dokan did not exist in Antiquity but formed as a result of dam building on the Lower Zab River in the 1950s. The sites indicated here came under water at that time.

\section{THE TOPOGRAPHY OF GRD-I TLE}

Fieldwork began in 2016, when a geodetic survey was conducted and a 10×10 metres reference grid was established across the whole site, to which the trenches could be oriented (Fig. 2). ${ }^{1}$ A 3D model of the hill was pro-

1 The topographical survey was prepared by Attila Weisz (Salisbury Ltd). Salisbury Ltd also provided other services assisting our excavations. 
Gábor Kalla - Tamás Dezsö • Hungarian Archaeological Expedition in the Mountains of Iraqi Kurdistan

duced, illustrating its geography, the top of the hill rising 30 metres above the surrounding suburban area. As of now, the area of the upper plateau measures $76 \times 86$ metres. Below, at about 10-12 metres height, there is a middle terrace, whose depth alternates between 10 and 25 metres, as its western side has already been destroyed by a modern road. Based on the surface features visible in the area of the upper plateau and the steep slopes of the mound, and the large amount of stones found all over the area, it was clear from the beginning of the project that on the top of the tell there are fortifications dating from subsequent periods.

Below the level of the plateaus, there is a $250 \times 210$ metres large "suburb", enclosed by an oval wall. The traces of this wall are still visible and are currently used as irrigation canals. The $600 \times 400$ metres large area of the outer town is situated outside of this.

In addition to the geodetic survey, a metal detecting survey was undertaken, which recovered a large number of 17 th-18th century coins and jewellery. ${ }^{2}$ This confirmed our earlier suggestions based on preliminary surface surveys that the site is covered by layers dating from the Late Islamic Period.

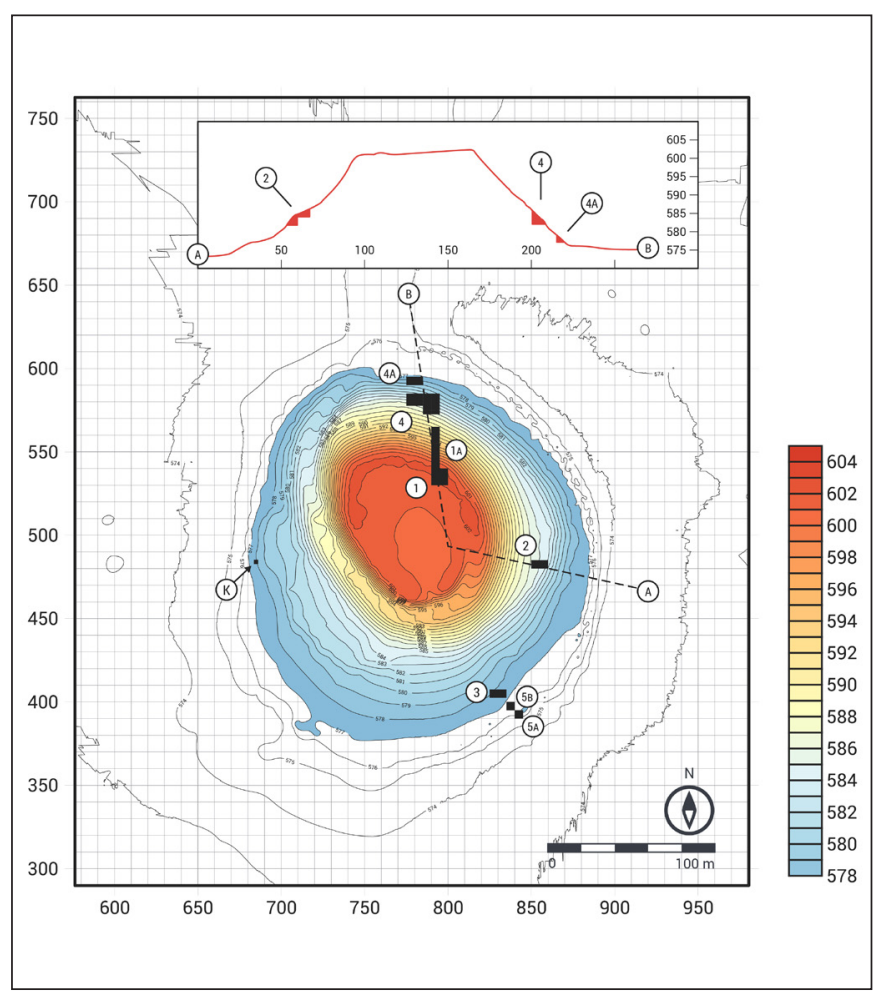

Fig. 2. Terrain contour map of the site of Grd-i Tle, showing the excavated surfaces. Area 4 includes Trenches 4, 4B, 4C and $4 D$. The section drawing shows how steep the hill is.

\section{PERIODISATION OF THE SITE}

During the four consecutive seasons, there were altogether five trenches opened, covering 12 grids, and it was possible to clarify many details concerning the history of the settlement and the formation of the site (Figs. 2-3). Although we did not yet reach the Prehistoric layers, the surface finds and the large amount of excavated materials revealed that the earliest period of the tell dates back to the Chalcolithic Halaf-horizon (6 millenium BC), and it was inhabited during the Ubaid (5th millenium and first half of the 4th millennium BC) and Uruk periods (second half of the 4th millennium BC) as well. The first two periods are characterized by a large number of flints and obsidian tools (KIRÁLY, 2017), as well as by painted ceramics, while the latter one by fragments of stoneware and the typical 'bevelled-rim bowls'. As of present, there is little information concerning later settlement periods, but during the last season, Ninive 5 and Early Bronze Age ceramics (beginning and first half of the 3rd millennium BC) were also found in Trench 1A, on the northern side of the hill, at about 8 metres

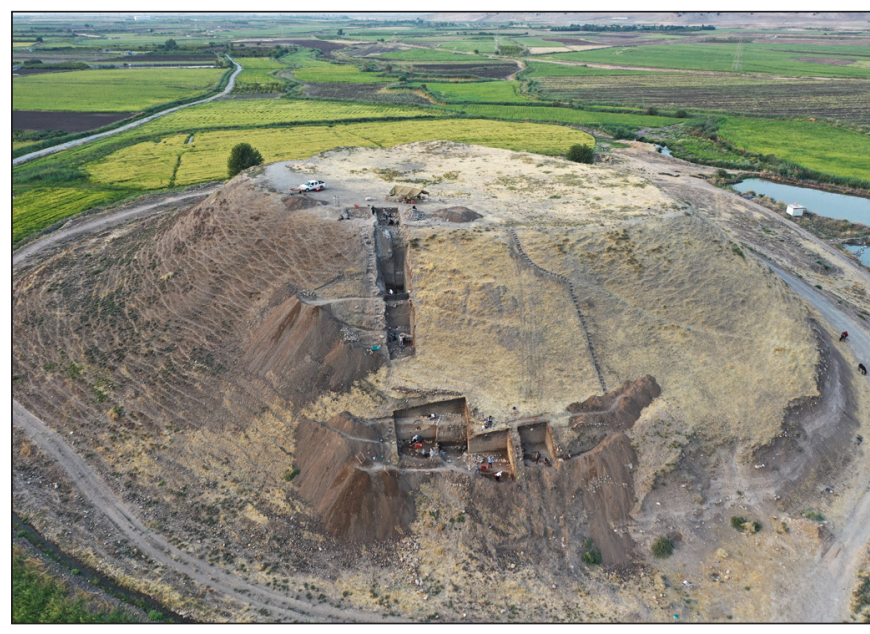

Fig. 3. Drone photo of the hill from the north, taken in 2019. On top, Trench 1 is to be seen (the modern fort and the Hellenistic-Parthian one under it); right below it, two sections of Trench $1 \mathrm{~A}$ are visible (the rubble of the modern, the Hellenistic-Parthian, and the Neo-Assyrian fort and the fill of the Neo-Assyrian terrace), as well as the HellenisticParthian layers of Trench 4. Trench 4 A cannot be seen in the bottom of the photo because it was buried after exploration in 2018. In the background there are agricultural lands with irrigation and fishponds.

2 The metal detecting survey was carried out by Lajos Sándor in 2016. 
depth. ${ }^{3}$ It is little known what could have happened between the Early Bronze Age and the Neo-Assyrian conquest (9th c. BC), but it seems that at least a few manorial centres could have existed here in the Middle and Late Bronze Ages. Since Trench 1A reached 24 metres in length in the last season, and the stratigraphy was in some places already 8 metres deep, it was possible to document long-term site formation processes. It turned out that on the original plateau of the hill — which was at about 22-24 metres height in the Paleolithic period - the Assyrians established terraces in order to build a fortress of a more substantial size, and to make this possible, the original top of the hill was elevated by a more than 4 metres thick earthen bank. The area below the citadel, which has not yet been excavated, was fortified by embankments (glacis). The lower sides of the hill were terraced.

At least 300 years passed following the abandonment of the Assyrian settlement, when in the Hellenistic-Parthian period a new fortification was probably constructed on the top of the ruins. The latest phase of this construction is represented by traces of a 4 metres thick wall found during the last season in Trench 1, above which the renewed walls of subsequent fortifications could be found, dating from the Islamic period.

The method of construction seems almost identical during these periods: the foundations and the footings of the walls were often built of stones bonded by clay, upon which mudbrick walls were raised. The only exception is the exterior wall of the Islamic fortress, where mortar was used. Only the size of stones used in the buildings seems different in the different periods. Other parts of the walls - in cases observed so far - must have been washed away by the heavy rainfalls during the winter and spring months, the effects of which could also be experienced during the excavation campaigns.

\section{THE ISLAMIC PERIOD}

In 2016, two trenches were opened in the area of the upper plateau (Area 1), where the remains of an 18th-19th century fortification could be documented, including an exterior wall with semi-circular bastions, inner precincts and a courtyard (Fig. $4) .{ }^{4}$ As for the exterior wall, the remains of an earlier, relatively thin $(80-90 \mathrm{~cm})$ and weak stone-and-mortar wall construction were reused and reinforced. Although the fortification has been destroyed to the ground, stones from this wall are still visible in many places, and on the southern side the outline of a gate structure could also be identified. The outbuildings in the precinct area were continuously renewed, built of brick walls standing on stone groundworks. There were at least ten building phases identified here. A set of circular features with gaping mouths

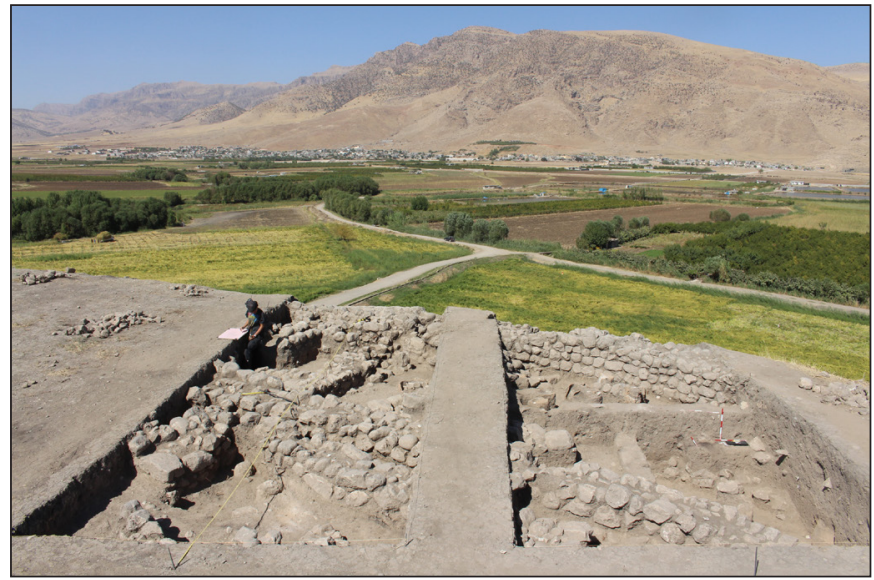

Fig. 4. Remains of the 18th-19th century Kurdish fort, seen from the terrace (Trench 1). There are rice fields and pomegranate gardens around the mound, with the village of Saruchawa and the Makuk Mountain in the background. atop - so called tennur-(tandur) ovens - were found in the ground of the courtyard. They were used for baking flatbread, feeding the garrisons. An interesting and unusual detail on the inside of the ovens were the cutmarks, which perhaps link to ancient Zoroastrian traditions. The most important diagnostic finds were pipe stems and Safavid coins. The fortress perhaps functioned as one of the centres of the Soran Emirate, which became temporarily independent from the Ottomans, but finally fell in 1835 . The systematic destruction of the walls might be connected to this event, and the characteristic assemblages, i.e. lead bullets, found inside the fort, as well as in the demolition lay-

Trench 1A was supervised by Tamás Dezső and Kristóf Fülöp.

4 The excavation of Area 1 was coordinated by Maxim Mordovin and Zsófia Masek in 2016 and Fruzsina Németh and Veronika Németh in 2019. 
ers covering the outer embankments could be also dated to the period of this siege (DEZsÖ - MoRDOvin, 2016; MASEK - Mordovin, 2016a; 2016b).

In 2017, in the southern area of the suburb (Area 5), a gate structure was found with stone foundations and rectangular towers. It possibly dates from this period too, although the masonry technique applied here is different from that of the fort. The wall was only $1.30 \mathrm{~m}$ thick, only the outer faces were masonry and the core was rammed clay. Based on the mixed finds, it remains unclear whether the gate and the connecting pieces of the town wall date back to the Islamic, or the Hellenistic-Parthian period (DEzső et al. 2017, pp. 384-390). ${ }^{5}$ The results of the metal detecting survey, as well as the details of an 18th-19th-century residential building, including an oven and a decorated bronze cup inside

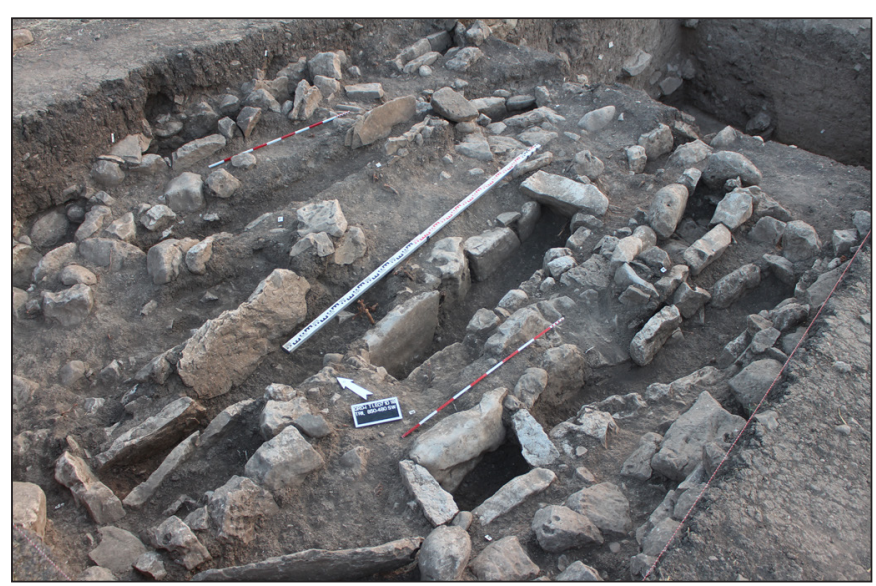

Fig. 5. 16th-century graves laid in stones on the eastern side of the mound, right below the surface (Trench 2). Above these there were a number of graves for new-born babies. The shape of the stones is highly varied; the material used was taken from the walls of earlier, abandoned buildings. of it, found in 2016 in the area of the suburb (Area 3) suggest the former option (DEzsö et al. 2016, p. 240), ${ }^{6}$ since this residential quarter must have also been protected. Because of the type of the masonry, however, it is also possible that this was the Hellenistic-Parthian town wall, on which the now destroyed medieval walls were built. Unfortunately, the remains of this double precinct wall cannot be investigated as they are used for the irrigation of the surrounding rice fields.

Another important group of features from the Islamic period were the burials found all over the eastern side of the hill. Although less densely, they also occurred on the northern side. There were two trenches opened on the eastern side, in the area of the middle plateau (Area 2), where around 50 graves could be documented during the 2016 and 2018 seasons (Fig. 5). ${ }^{7}$ They were densely packed within an approximately $40 \mathrm{~m}^{2}$ large area, and there were several others found in 2019, in Trenches 1A, 4B and 4D. During the 2016 excavation of Area 2, two phases of the cemetery could be clearly observed: in the earlier one, the distribution of the graves was more diffuse than in the later phase. In the earlier phase, the dead were laid in the graves on their right sides, in shallow and narrow pits, covered by longish stones. As for the later phase, the dead were laid in a supine position, in wider and deeper pits, lined with flat stones, which were positioned upright and were covered by larger flat stones. These were basically irregular shaped stone cist graves. In both phases, the bodies were oriented east-west, facing east, in the direction of Mecca. The stones used were undressed rubble stones, collected from earlier structures, and the different shapes and sizes were used pragmatically, resulting overall in irregular shapes. There were no grave finds, and there was a high ratio of subadults in the population of the cemetery, including infants and new-born babies, whose graves were usually in close proximity to adults' graves, placed next to, or above them. In the latter case, no separate grave-pit was observed (KALLA - SzABÓ, 2016). Based on the radiocarbon dates from bone samples, the earlier phase could be dated to the second half of the 12 th century, and the later one roughly to the 16 th century. ${ }^{8}$ This means that the cemetery and the late Islamic period of the settlement, which we have been investigating so far, did not belong together.

\section{THE HELLENISTIC-PARTHIAN PERIOD}

During the period following the conquest of Alexander the Great (333-323 BC), there was a particularly strong Mediterranean influence in the area of the Zagros Mountains, which did not cease with the emer-

\footnotetext{
Area 5 was supervised by Ardalan Khwsnaw and Aram Ali Hama Amin in 2017.

6 Excavations in Area 3 were coordinated by Nóra Szabó in 2016.

The excavation of Area 2 was supervised by Gábor Kalla. In 2016, Nóra Szabó, in 2018 Veronika Németh provided assistance.

8 We hereby thank Zsuzsanna Siklósi for calibrating the measurements provided by the Institute of Nuclear Research of the Hungarian Academy of Sciences (MTA ATOMKI).
} 
Gábor Kalla - Tamás Dezsö • Hungarian Archaeological Expedition in the Mountains of Iraqi Kurdistan

gence of the Parthian Empire (3rd c. BC - 3rd c. AD). Since local traditions of pottery making prevailed - and at the moment there are no better diagnostic finds available - the two periods cannot be separated chronologically. The most important diagnostic finds at the site were two Macedonian silver coins, for example, a tetradrachm minted in Lampsacus between 310-301 BC, which was found in Area 2 (Fig. 6; Dezső et al., 2016, p. 239). Apart from ceramic finds, the Mediterranean type roof tiles, i.e. flat tiles with raised edges (tegula) and semi-circular ones (imbrex), are also reliable tools for dating, as they were in use in this region only during this period and there were many fragments found.

As could be detected in different places during the excavations, buildings dating from the earliest phase of this period rested directly on earlier structures dating from the Neo-Assyrian period; oftentimes directly following the direction of these walls.

In 2017, a 1 meter thick east-west oriented wall was found in Area 4, and in 2019 the continuation of this wall could be detected also in Trench 4B (to the east) and in Trench 4C (to the west) (Fig. 7). Since most part of this building remains still buried under the hill, it is not possible to tell anything about its character; however, it seems likely that it was a large residential building. It stood right $30 \mathrm{~cm}$ above the remains of a Neo-Assyrian house, and its fill was mixed with a large number of finds of particular importance, dating from earlier periods (see below).

In 2018, the remains of a representative building

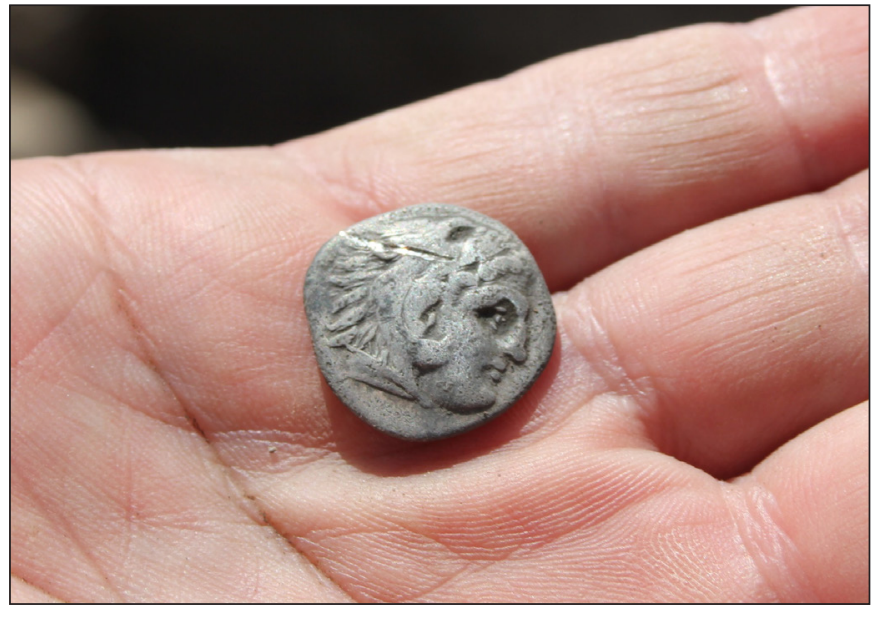

Fig. 6. The Macedonian silver tetradrachm found in Trench 2 in 2016. It was minted in Lampsacus between 310-301 BC.

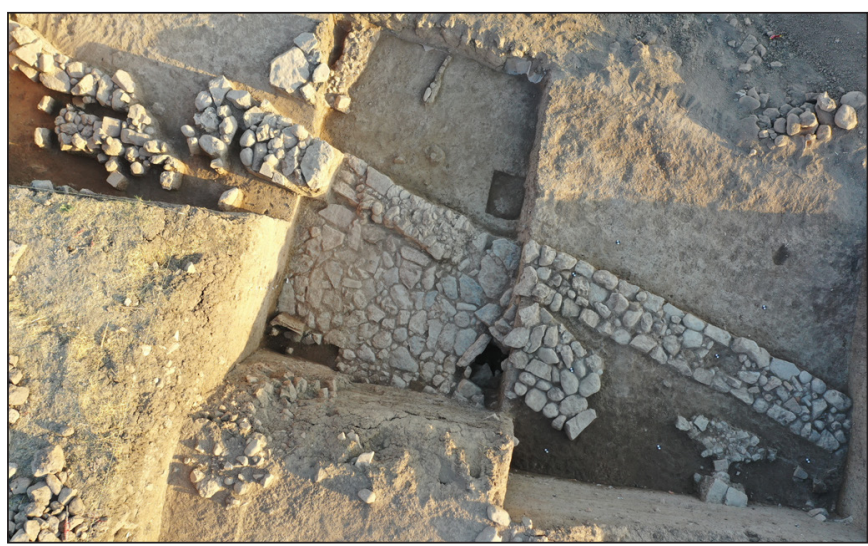

Fig. 7. Drone photo of the Trenches $4,4 B$ and $4 C$ at the end of the 2019 excavation season. In the middle there is the excavated Neo-Assyrian house with a paved yard; to the left and right, walls associated with two construction periods of a Hellenistic-Parthian building, built on top of the house, are seen. were found in Area 2, situated similarly above the traces of a Neo-Assyrian house. There was a courtyard in the building, covered with large stone slabs, and Neo-Assyrian ceramic sherds collected in place were used for levelling the slabs (KALLA - DezsÖ, 2019).

In 2019, a thick wall was found in Trench 1A, which possibly dates back to this period. As regards the interpretation of such remains (walls), we were always facing the same issue, namely that due to the at least 3 metres deep stratigraphy, only small surfaces could be investigated at once, and since the erosion usually destroyed the levels of floors, it was difficult to see what structures the walls were part of, e.g. whether they were buttresses of the plateaus, or buildings. The two roles could be also interrelated, as the slope could be terraced and the buildings needed buttresses, similarly to the Neo-Assyrian period.

Above the earliest layers from the Hellenistic-Parthian period, one could observe also on the eastern (Area 2) and northern (Area 4, Trench 4B and Trench 4C) ${ }^{9}$ sides of the hill at least 2 metres deep sequences of deposits, including features related to industrial activities, predominantly bases and wall fragments of demolished kilns. ${ }^{10}$ The deposits included a large amount of charcoal, as well as iron- and glass-slag. In Trench 4B, a kiln was excavated in 2019, whose walls were well-preserved, up to the level of its perforated floor above the combustion chamber, the inside of which was almost completely covered by molten glass

9 The 2019 excavation of Trench 4B was supervised by Gábor Kalla, Trench 4C by Attila Király, and Trench 4D by Nóra Szabó.

10 For the 2017 observations concerning Area 2, see: Dezsö, Kalla et al., 2017, 371-377. 
Gábor Kalla - Tamás Dezső • Hungarian Archaeological Expedition in the Mountains of Iraqi Kurdistan

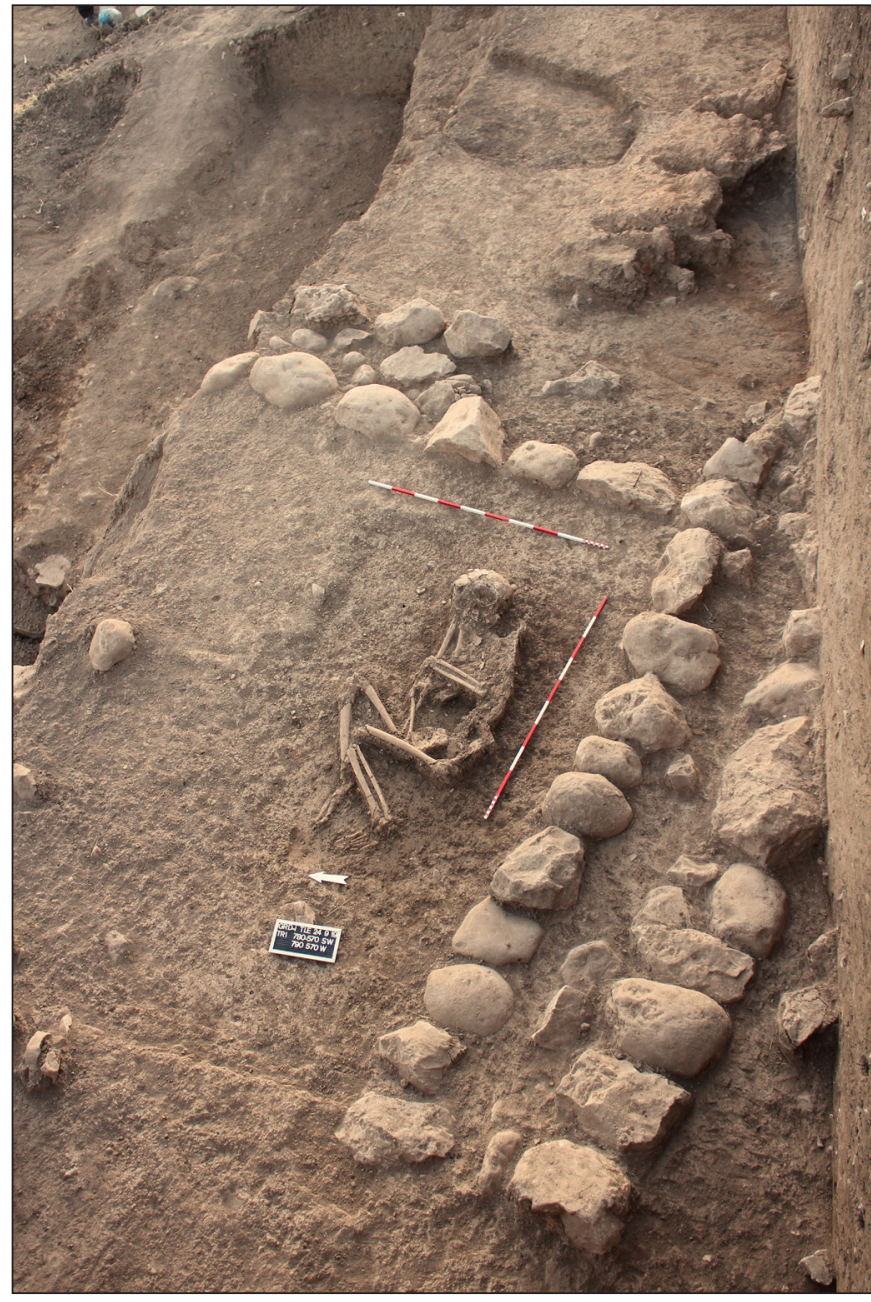

Fig. 8. The latest Hellenistic-Parthian house in Trench $4 B$. In the foreground there is a grave dated after the abandonment of the house but to the same period. In the background the upper part of a kiln is seen, dated earlier; it was probably used for glazing pottery.

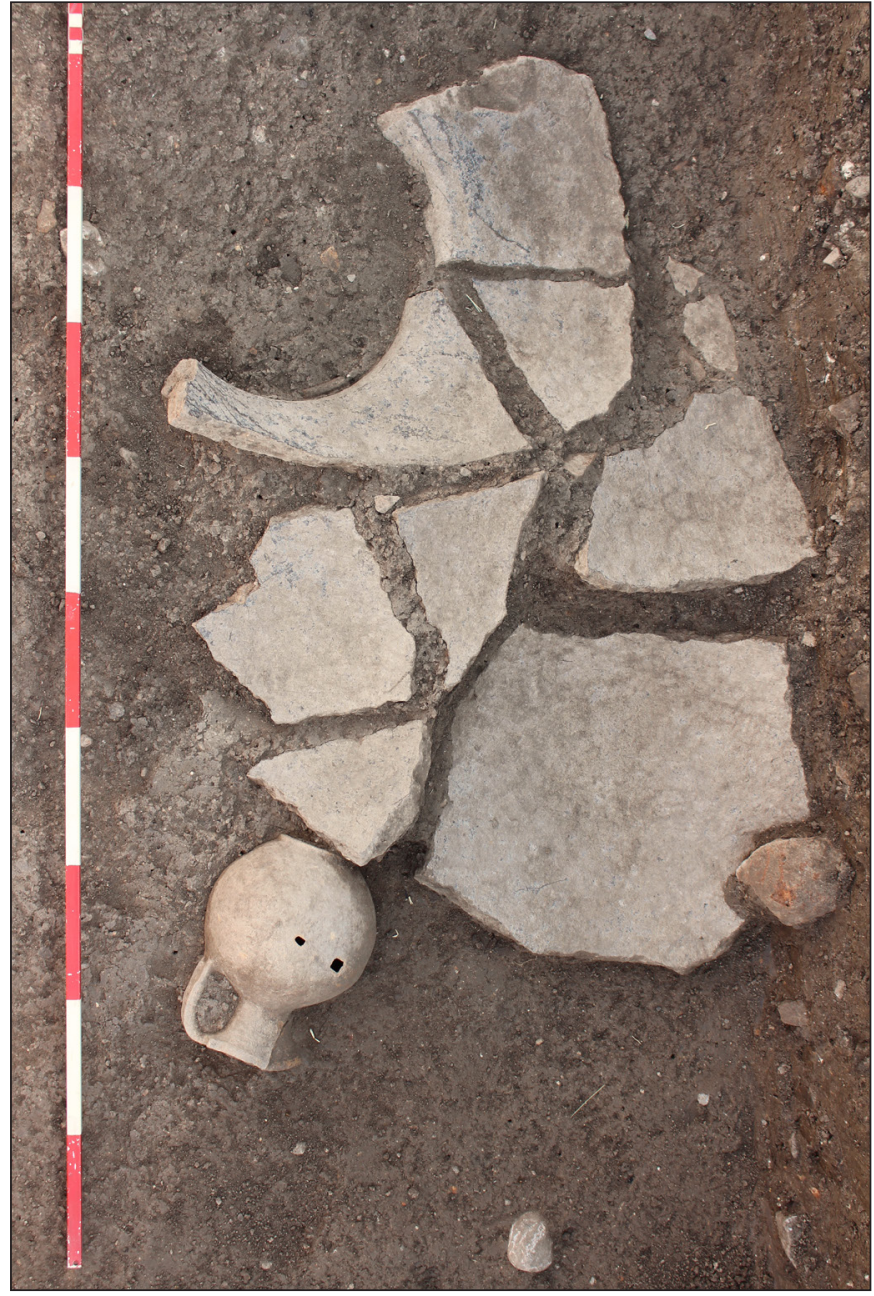

Fig. 9. A deposition of vessels from the Hellenstic-Parthian period: an intact wine jug (oinokhoe) and fragments of a large storage vessel (pithos) (Trench 4B).

(Fig. 8). The lower parts of two similar kilns were excavated in Trench 4C. They were perhaps used for glazing pottery, however, there were no spoiled pieces found until now. Other kilns could be used perhaps for processing iron. There seems to have been a constant activity of levelling up the floor, as worn out kilns were frequently destroyed, in place of which new ones could be constructed. This observation suggests that part of the settlement functioned as an industrial zone for a long period.

Residential buildings from the third phase of the Hellenistic-Parthian period were identified in Area 2 in 2016 and 2017 (Dezső et al., 2016, pp. 371-377) and in Trench 4B in 2019, however, their floor levels were not found in either case. In Trench 4B, a contracted burial was found, post-dating the building (Fig. 8), whose accessories included an iron knife, an iron arrow head, and a bone bow grip. Above the grave, there were a couple of pottery deposits found, some of which consisted only of one, others but a few pots. These finds are important as they represent the first intact, or completely restorable vessels from this period (Fig. 9).

In 2019, the surface of Area 1 in the upper plateau was re-opened, and below the Islamic period layers, at about 2 metres depth, we reached the level of the Hellenistic-Parthian fortification walls, the debris of which was spread over the northern embankments of the hill, as identified earlier in Trench 1A (Dezsö et al., 2017, pp. 364-369). The massive wall was 4 metres thick, made of relatively large stones bonded by clay. Based on what we have experienced so far, the walls of the Neo-Assyrian citadel should be somewhere below this wall. In 2018, we already identified a massive buttress wall of the terrace in the upper part of the mound, in Trench 1A, 4 metres below ground. 


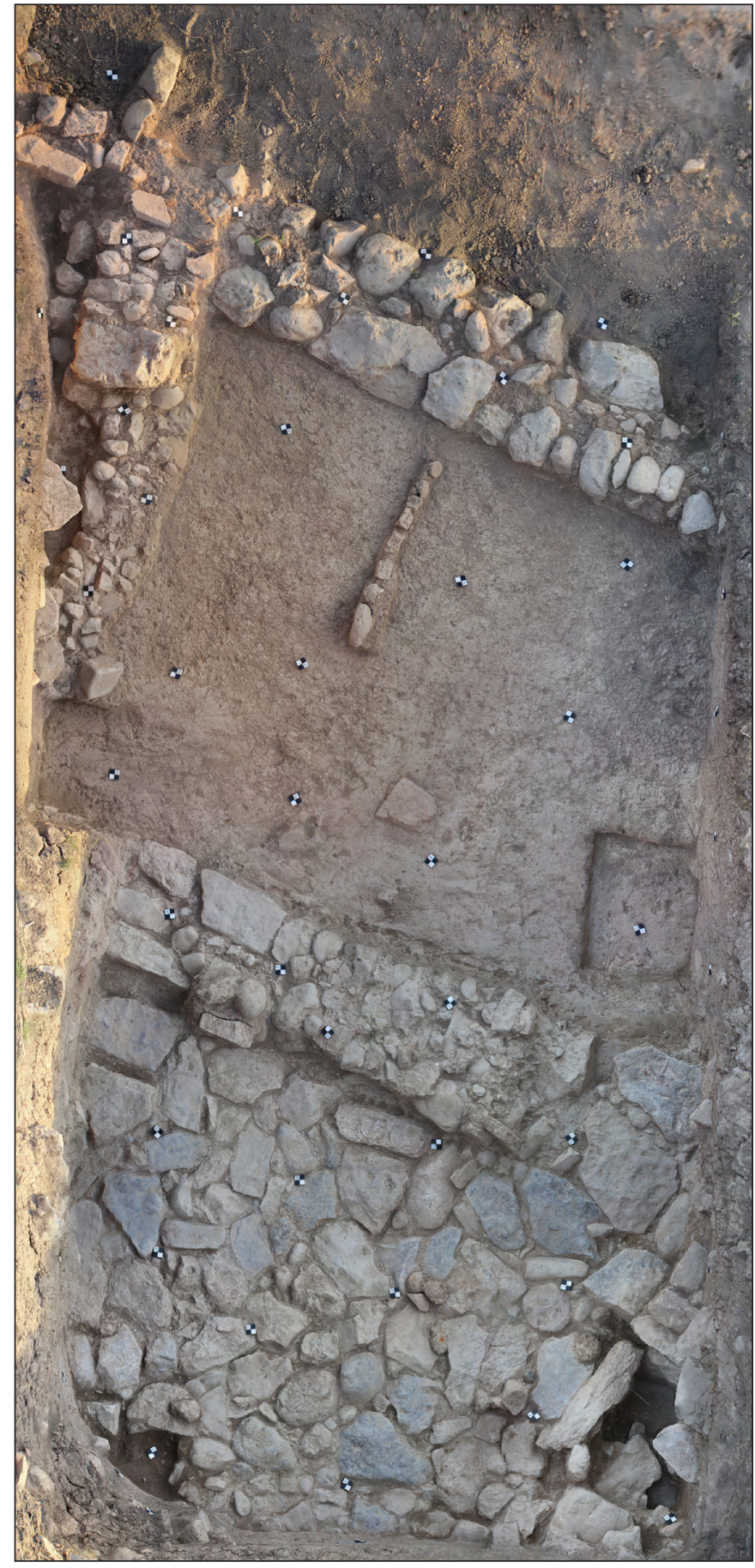

Fig. 10. Trench 4 with parts of a Neo-Assyrian residential building and paved courtyard, unearthed in 2018. On the top, a room that was probably used for beer production is seen. Vessels used in brewing were found standing along the small wall segment in the middle of the room (ortophoto by András Bödöcs).

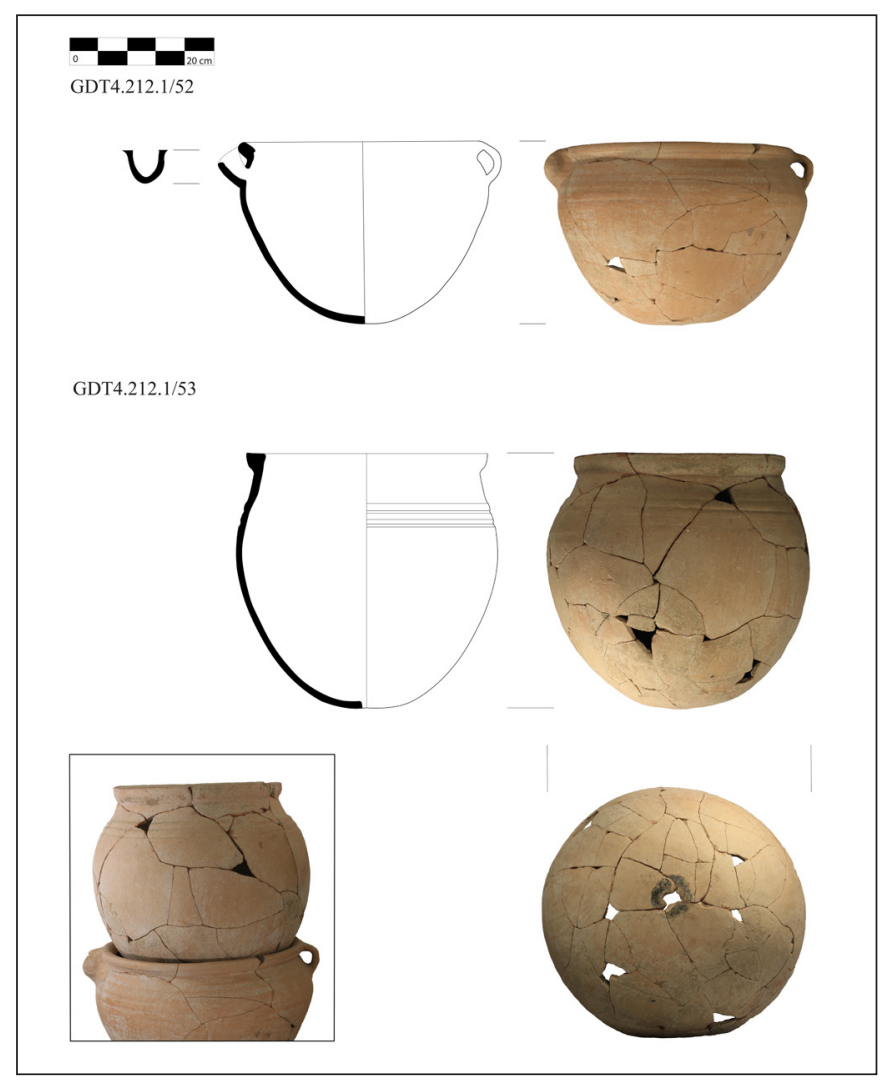

Fig. 11. Brewing vessels discovered in the Neo-Assyrian layers of Trench 4. The vessel with the pierced bottom, greased with bitumen, must have been placed on top of the nosed vessels, as seen here.

\section{THE NEO-ASSYRIAN PERIOD}

Surveying the archaeological remains of the Neo-Assyrian period, as envisioned by the project, posed huge difficulties at the beginning, as it turned out that there is a thick debris from later periods covering the top of the hill. However, the 2018 campaign was a breakthrough, as we managed to find Neo-Assyrian layers in four different locations at once (KALLA Dezsö, 2019). It also became clear that the easiest way to reach these layers was to excavate on the northern side of the mound, below the middle plateau, where the hill was less than 10 metres high.

We opened Trench 4 and 4A in this area, and they were oriented in the same way as Trench 1, in order to have them form a continuous section extending altogether to a depth of 3-4 metres at least. In Trench 4, the remains of a Neo-Assyrian house were found, right below the Hellenistic-Parthian wall, which was identified in the previous season (Fig. 10). ${ }^{11}$ Based on the proportions of the building, the total area of the house is estimated to be about $150-200 \mathrm{~m}^{2}$ at least, of which approximately $35 \mathrm{~m}^{2}$ have been excavated: two rooms, including parts of the courtyard and a service room. Apparently, the owner of the house must have been someone influential, most probably an Assyrian office-holder. The stone paving of the courtyard

11 The excavations in Area 4 were supervised by Attila Király. 
was indicative of this, as this feature is generally unusual in the territory of the Assyrian Empire, and can be found only in case of more representative residential buildings (Miglus 1999, pp. 131-175, Taf. 64-85). Clearly, the use of spectacular polychrome decoration was preferred in this case, as the white, grey, red and blue stones were all carefully selected and put in place.

Two doorways opened from the courtyard to a service room with rammed floor, which must have been used as a kitchen and brewery. A tennur-oven and next to it three thin walled vessels, with a compartment capacity of roughly 18 litres, were found there. Two of the vessels had noses below their rims, and the third one had a hole in its bottom, the frames of which were greased with bitumen (Fig. 11). The first two vessels were placed in holes made in the ground, next to a low wall running north-south in the middle of the room, and they were fixed in position with stones and ceramic sherds. Until now, there has been no example of brewing equipment known from the Neo-Assyrian period, however, based on similar finds from earlier periods (the Middle and Late Bronze Ages) the vessel with the pierced bottom must have been used for fermentation. It could be placed on top of the nosed vessels, into which the liquid beer was dripping, through a piece of cloth. There were also several other tools found in the room, which could be used for processing grain, including e.g. a pestle for grinding and some other vessels.

In 2018, we found many other artefacts, e.g. sherds of glazed ceramics, in the debris of this building, which also suggested the elite status of the household, as they were very expensive objects at that time. In 2019, we continued to excavate the building in three different trenches (Trench 4B, 4C, 4D; Fig. 6). Although we barely managed to reach the Neo-Assyrian layers - and we could not explore them due to other important findings dating from later periods - this excavation campaign yielded the most unique finds and the results are already significant.

Namely, there was a great number of unique Neo-Assyrian household items found in the layers dating from later periods, including e.g. an Egyptian scarab beetle made of faience (quartz) ceramics and decorated with hieroglyphic script, two scaraboid sealing stamps made similarly of faience, and so-called Egyptian blue beads and clasps - all Egyptian and Phoenician import objects. Carnelian beads imported from Eastern Iran were also found. On the other hand, fragments of glazed ceramics and of well-tempered, thin walled vessels (the so-called Palace Ware) indicate the connections of this household to the core territory of the Assyrian Empire.

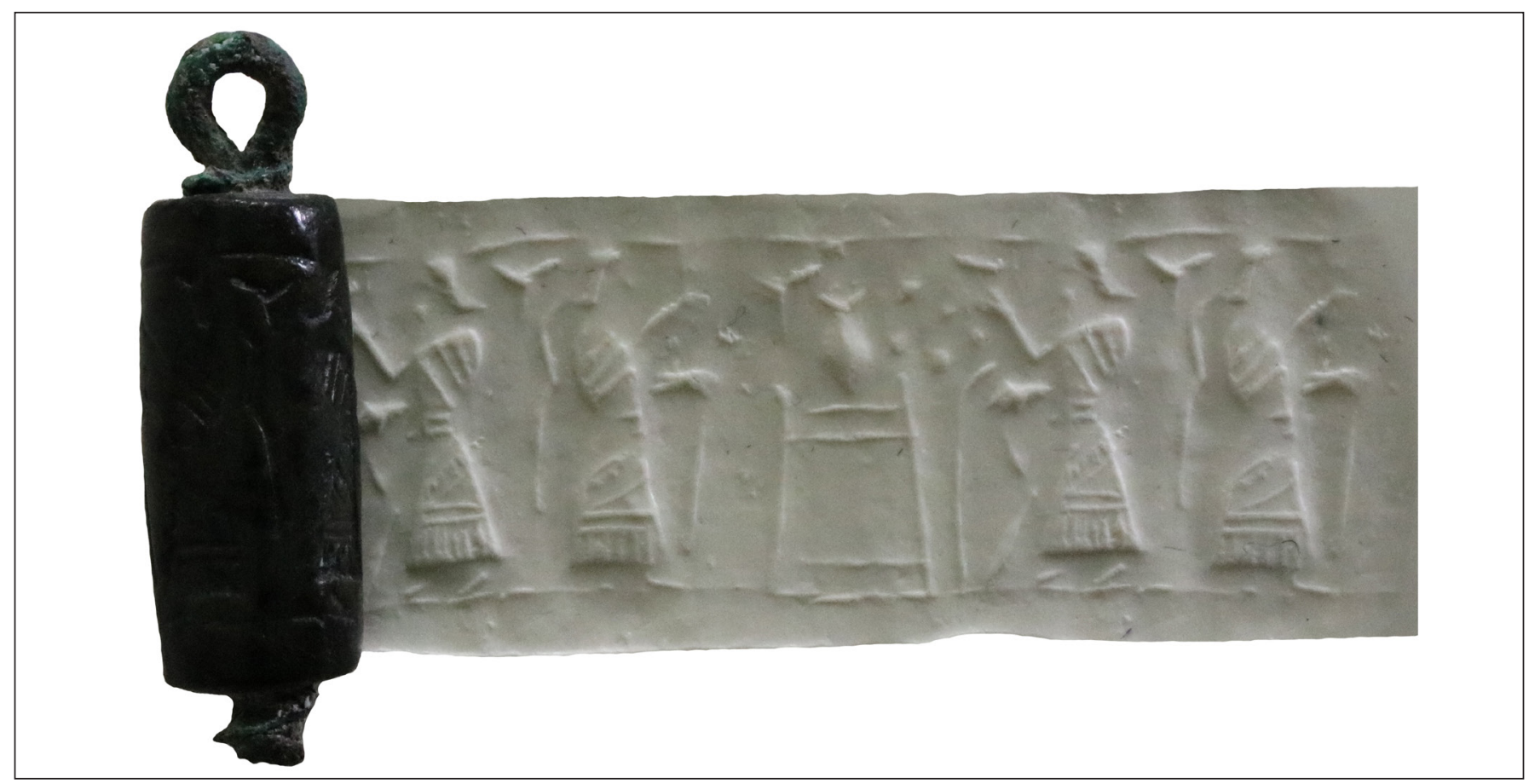

Fig. 12. Neo-Assyrian stamp-cylinder found in Trench 4B. The piece is made of serpentine and depicts a ritual scene with the king and a high-ranking officer. This is the first Assyrian stamp-cylinder to be found in the region. 


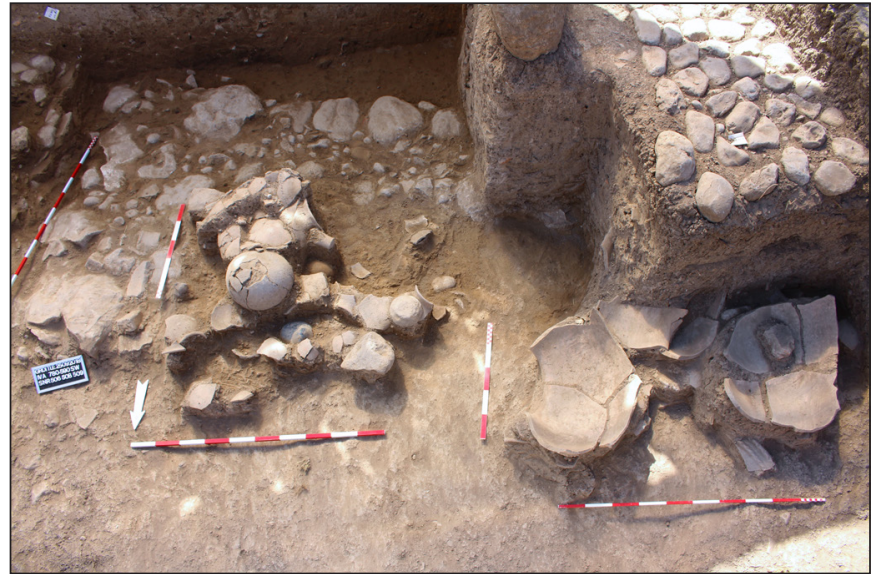

Fig. 13. Room of the Neo-Assyrian house with piled-up vessels and stone tools in Trench 4A, excavated in 2018. Above the pile the paved courtyard of a house associated with the next construction phase is seen.

One of the most important finds of the season was a serpentine stamp-cylinder with a bronze handle (Fig. 12), which confirmed the assumption that the house could be the residence of a high-ranking Assyrian officer. The surface of the $2.3 \mathrm{~cm}$ long and $1 \mathrm{~cm}$ wide object was decorated with a ritual scene, depicting the Assyrian ruler surrounded by office-holders. As the surface of the cylinder is heavily worn, it was likely used for a long period of time. The so-called "linear style" of the decoration reflects a very much simplified iconography, which can be interpreted, however, on the basis of analogies, of which a great number is known. ${ }^{12}$ Standing on one side, there is the figure of the ruler, lifting a cup with his right hand, and holding a bow in his left hand as the symbol of his military power. On the other side, there is an officer, wearing a shawl, holding a flag-like fan in his left, and a spectre — as a status symbol —in his right hand. Between the two figures there is a ritual table with a vessel on top. This ritual scene, as an assertion of royal power appears also on reliefs in palaces, and the stamp-cylinders were, in fact, spreading this iconographical message throughout the whole empire, as demonstrated by the distribution of such objects. Although there is no unambiguous evidence for this, it seems highly likely that this type of object was used by mid-rank officials of the Assyrian Empire.

In 2018, another Neo-Assyrian house was found at the bottom of the northern slope of the hill, and some parts could be detected right below the topsoil in Trench 4A. ${ }^{13}$ Due to the mixed finds, it is not possible to decide at the moment whether the paved courtyard, found right above the remains of the house, was part of a renovation phase of the building, i.e. still dating from the Neo-Assyrian period, or belonged to the Hellenistic-Parthian era. Below the level of the courtyard, a large amount of finds could be recovered, basically in two groups, but within a tiny area (Fig. 13). Almost intact pieces of fine ceramic vessels, cooking and storage vessels, coarse ware (jugs and cups) and processing stones were found in a position as if deliberately piled up. Most ceramic vessels were local products, reflecting Iron Age traditions; the fine pieces, however, were Assyrian types. The stones, pestles, and the grinding stones were archaic tools. This mixture of high-status objects and household ceramics nicely illustrates the process of cultural integration following the Assyrian conquest.

Since the residential buildings of the Assyrian period were built on terraces carved out of the hillsides, there was a $9 \mathrm{~m}$ difference in the elevations of the roughly contemporaneous buildings in Trench 4 and $4 \mathrm{~A}$, although there was only 10 metres distance between them.

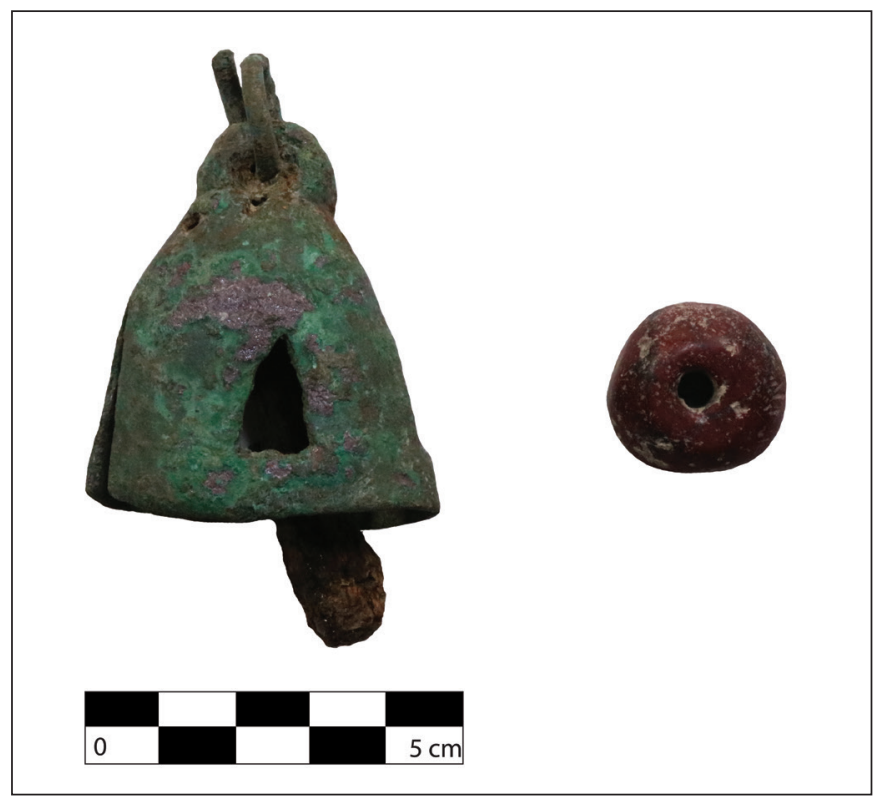

Fig. 14. A bronze bell with an iron grip, and a red stone bead with black marbling. These objects, discovered next to each other above the Neo-Assyrian building, were probably decorative elements of a horse harness.

\footnotetext{
12 See e.g. Collon, 2001, 64-70, Plates IX-X.

13 The excavation of Trench $4 \mathrm{~A}$ was supervised by Nóra Szabó.
} 
On the eastern side of the hill, in Trench 2, there was yet another house found in 2018, dating from the Neo-Assyrian period (KALlA - Dezsö, 2019). Its walls were 1.20-1.30 meter thick, and in their foundations holes were observed which probably accommodated vertical beams and could be complemented by horizontal ones reinforcing the mud-brick structure of the wall. The beams were not necessarily attached to one another, but they made the structure more flexible in case of an earthquake; this was a well-known architectural feature in the Syrian-Anatolian region (NAUMANN 1971, pp. 86-108), where this landscape belonged also in a cultural sense. The remains of a sacrificial offering were found in the wall: in a depression of a larger piece of stone, a small, hand shaped vessel was found in an ashy deposit, which could have served for the preparation of some ritual food. The size of the wall suggests that the building was fairly large. It was perhaps a small palace, however, this could not be confirmed due to the small size of the excavated area. Finds from this layer and other objects from earlier seasons, e.g. a lazurite stone, carnelian beads, and a bronze bell with an iron grip point to a high-status household (Fig. 14). This latter might have been used as harness decoration, together with a red stone bead, since they were found together. Horses were particularly expensive at that time, and it was right this region - the Iranian Mountains, one of the most important horse-breeding and training regions of the world — that supplied horses to the Assyrian army (DEzsö 2016a, pp. 167-188).

There is no information concerning the size of the settlement, or how significant it was as a central place, since the historical suburb cannot be investigated archaeologically due to the high water table, the fishponds, and the rice fields currently occupying the area. Judging from the scattered surface phenomena, it was certainly occupied in the Hellenistic-Parthian period, and certain metal finds suggest that this occupation dates back to even earlier times, but this cannot be clarified with certainty at the moment.

The rich materials of the Assyrian period, the assemblages of household items were well-preserved, and could remain relatively complete due to the fact that they had been covered by a later destruction layer. The date of this event could not be determined yet, however, the large number of Scythian type bronze and Assyrian type iron arrowheads, which kept coming up since the very first campaign, hint on a major event. In Trench 4, in the debris of the Assyrian house, disintegrated human remains were found (Dezsö 2016b). Although tri-lobed Scythian arrowheads were not used exclusively by the Scythians, we know that during the time of the Assyrian ruler Assur-ah-iddina (680-669 BC), the Empire suffered a devastating attack by the Scythians storming in from the neighbouring region (RADNER 2016, p. 21). The destruction of this settlement fits into the course of these events, but it could be related also to the fall of the Empire in 614-609 BC. If the renewal of the stone paved floor in Trench 4A proves to date back to the Neo-Assyrian period, the former theory seems more reasonable, but this requires in any case further investigations.

\section{SUMMARY}

Our excavations took place altogether during four short seasons, one month each, the time of which was further limited by the necessary tasks to uncover and cover the trenches before and after each season. However, the project yielded significant results. Several details of the history and topography of Grd-i Tle could be clarified, as well as the local characteristics of Islamic and Hellenistic-Parthian heritage. The central administrative role of the settlement in the Assyrian period was also confirmed, and there important assemblages were found which will allow to reconstruct complete households - thus, it will become possible to study the relationship between the centre and the periphery of the Neo-Assyrian Empire on the level of individual households. As for investigating economic activities, a botanic analysis is currently being carried out in order to process macrobotanical samples collected by flotation. In 2019, geological and geophysical investigations were conducted. ${ }^{14}$ The results are under evaluation, but it is clear by now that here was the most well-irrigated and the most fertile part of the Rania-plain in Antiquity.

${ }_{14}$ Geological investigations were conducted by István Viczián, and the geomagnetic surveys by Ádám Vér (assisted by Gergely Surányi). 
Gábor Kalla - Tamás Dezső • Hungarian Archaeological Expedition in the Mountains of Iraqi Kurdistan

In addition to fieldwork activities, the processing and documentation of the finds continued in the base camp, and their restoration has also started from this season. ${ }^{15}$ It is important to note that this was the first Hungarian archaeological expedition to study Mesopotamian culture.

\section{BIBLIOGRAPHY}

Collon, D., 2001.

Cylinder Seals V. Neo-Assyrian and Neo-Babylonian Periods. Catalogue of the Western Asiatic Seals in the British Museum. London: British Museum.

Dezsö, T., 2016a.

The Assyrian Army II. Recruitment and logistics. Budapest: Eötvös University Press.

DeZsö, T., 2016в.

The arrowheads from Grd-i Tle (Rania Plain, Iraqi Kurdistan). Dissertationes Archaeologicae Ser. 3(4), pp. 97-112. doi: http://dx.doi.org/10.17204/dissarch.2017.97

Dezső, T., Kalla, G., Mordovin, M., Masek, Z., Szabó, N., et al., 2016.

Grd-i Tle 2016. Preliminary Report of the Hungarian Archaeological Mission of the Eötvös Loránd University to Grd-i Tle (Saruchawa) in Iraqi Kurdistan. Dissertationes Archaeologicae Ser. 3(4), pp. 233 240. doi: http://dx.doi.org/10.17204/dissarch.2015.233

Dezsö, T., Kalla, G., Baiz Ismail, B., Bödöcs, A., FülöP, K., ET AL., 2017.

Preliminary Report on the Hungarian Archaeological Mission (Eötvös Loránd University) at Grd-i Tle (Saruchawa) in Iraq: Second Season (2017). Dissertationes Archaeologicae Ser. 3(5), pp. 361-392. doi: http://dx.doi.org/10.17204/dissarch.2017.361

Dezső, T. \& Mordovin, M. 2016.

The first season of the excavation of Grd-iTle. The Fortications of Grd-iTle (Field 1). Dissertationes Archaeologicae Ser. 3(4), pp. 241-262. doi: http://dx.doi.org/10.17204/dissarch.2015.241

Kalla, G. \& Dezső, T., 2019.

The Hungarian Excavations at Grd-i Tle (Ranya-Plain). In: Z. Bradosty, A. Zibare, H. A. Abdulrahman, M. O. Aziz, \& Ğ. 'at Șalaḥ ad-Dīn, eds., Proceedings of the 3rd International Scientific Conference Archaeology and Heritage in Kurdistan. Erbil: Salahaddin University, pp. 630-645.

KIRÁLY, A., 2017.

Grd-i Tle knapped and ground stone artefacts, excavation seasons 2016-2017. Dissertationes Archaeologicae Ser. 3 (5), pp. 83-96. doi: http://dx.doi.org/10.17204/dissarch.2017.83

MacGinnis, J., Wicke, D., \& Greenfield T., EDS., 2016.

The Provincial Archaeology of the Assyrian Empire. Cambridge: Oxbow Books.

15 Eszter Tóth was responsible for the restoration of the finds; in addition to the aforementioned archaeologists, András Füzesi, Abdullah Bakr Othman, Maha Suleiman, and Noémi Fuchs took part in processing the ceramic finds. 3D photos were created by András Bödőcs. The following BA students took part in the excavation and processing of finds: Regina Kapitány, László Almády, Sára Kovács, Bertalan Pillik. 
Gábor Kalla - Tamás Dezsö • Hungarian Archaeological Expedition in the Mountains of Iraqi Kurdistan

Masek, Z., \& Mordovin, M., 2016A.

The first season of the excavation of Grd-iTle. The post-medieval settlement at Grd-i Tle (Field1). Dissertationes Archaeologicae Ser. 3(4), pp. 277-289. doi: http://dx.doi.org/10.17204/dissarch.2015.277

Masek, Z,. \& Mordovin, M., 2016B.

Az Oszmán Birodalom végvidékén... Irakban [On the borders of the Ottoman Empire... Iraq]. Várak, kastélyok,templomok 12(1), pp. 120-122.

Miglus, P. M., 1999.

Städtische Wohnarchitektur in Babylonien und Assyrien. Baghdader Forschungen 22. Mainz: von Zabern.

NAUMANN, R., 1971.

Architektur Kleinasiens von ihren Anfängen bis zum Ende der hethitischen Zeit. Tübingen: Wasmuth.

RADNER, K., 2016.

The Peshdar Plain in the Neo-Assyrian period: the Border March of the Palace Herald. In: K. Radner, J. F. Kreppner, \& A. Squitieri, eds., Exploring the Neo-Assyrian Frontier with Western Iran. The 2015 Season at Gird-i Bazar and Qalat-i Dinka. Peshdar Plain Project Publications 2. Gladbeck: PeWe Verlag, pp. 17-22. 